\title{
PELATIHAN PENCATATAN KEUANGAN MENGGUNAKAN APLIKASI SiAPIK PADA UD BITATA FOOD BANDA ACEH
}

\author{
Hamdani $^{1}$, Thasrif Murhadi ${ }^{2}$, Saiful Bahgia ${ }^{3}$ \\ ${ }^{1,2,)}$ Program Studi Manajemen Keuangan Sektor Publik, Politeknik Kutaraja \\ ${ }^{3)}$ Program Studi Akuntansi, Politeknik Kutaraja \\ e-mail: hamdani@poltekkutaraja.ac.id
}

\begin{abstract}
Abstrak
Kegiatan Pengabdian kepada Masyarakat $(\mathrm{PkM})$ yang dilakukan berorientasi pada pencapaian output untuk meningkatkan kapasitas UMKM UD Bitata Food Banda Aceh pada aspek keuangan telah menunjukkan hasil yang memuaskan. Permasalahan laporan keuangan telah lama menjadi persoalan klasik pada UMKM bahkan telah menempatkan hal itu sebagai masalah utama UMKM. Tujuan dari pengabdian ini yaitu perguruan tinggi sebagai lembaga keilmuan dan layanan pendidikan untuk memberikan manfaat seluas-luasnya bagi masyarakat dengan meningkatkan kapasitas subyek pengabdian. Adapun metode yang diterapkan pada pengabdian ini adalah pelatihan. Metode ini dipilih menyandarkan pada kebutuhan, kemampuan, dan pertimbangan akademis pengabdian untuk mencitptakan solusi yang diharapakan oleh UD Bitata Food. Hasil pelatihan peserta telah mendapatkan pengetahuan yang mendasar mengenai keuangan usaha yang selama ini belum pernah disusun sesuai standar. Pengetahuan peserta pelatihan diukur dengan hasil wawancara paska pelatihan dilakukan. Selain itu subyek juga telah dapat mendaftarkan usahanya untuk mendapatkan akun SiApik yang digunakan untuk pencatatan keuangan usaha secara berkelanjutan. Sedangkan peserta yang dilatih menjadi operator akun SiApik telah mampu menginput data sesuai dengan menu yang disediakan layaknya menyusun laporan keuangan usaha. Kendatipun pengabdian ini telah mencapai hasil yang memuaskan kedua pihak namun keberlanjutan program ini tetap diteruskan dengan pola mentoring dan pendampingan.
\end{abstract}

Kata kunci: UMKM, Laporan Keuangan, Pelatihan, Aplikasi SiApik, Mentoring, Pendampingan Usaha

\begin{abstract}
Community Service Activities ( $\mathrm{PkM}$ ) which are oriented towards achieving output to increase the capacity of UD Bitata Food Banda Aceh's MSMEs in the financial aspect have shown satisfactory results. The problem of financial statements has long been a classic problem for MSMEs and has even placed it as the main problem for MSMEs. The purpose of this service is that universities are scientific institutions and educational services to provide the widest possible benefits to the community by increasing the capacity of the subjects of service. The method applied to this service is training. This method was chosen based on the needs, abilities, and academic considerations of dedication to create the solutions expected by UD Bitata Food. As a result of the training, participants have gained basic knowledge about business finance which has never been prepared according to standards. The knowledge of the trainees was measured by the results of post-training interviews. In addition, the subject has also been able to register his business to get a SiApik account which is used for recording business finances on an ongoing basis. Meanwhile, participants who were trained to become SiApik account operators have been able to input data according to the menu provided, just like compiling a business financial report. Although this service has achieved satisfactory results for both parties, the sustainability of this program is still continued with a pattern of mentoring and mentoring.
\end{abstract}

Keywords: MSMEs, Financial Reports, Training, SiApik Applications, Mentoring, Business Assistance 


\section{PENDAHULUAN}

Usaha Mikro Kecil dan Menengah (UMKM) di Indonesia merupakan unit usaha yang umumnya dimiliki oleh masyarakat kelas menengah ke bawah atau tingkat akar rumput yang jumlah modalnya sangat terbatas. Menurut laporan Kementerian Koperasi dan UKM (2020), komposisi UMKM didominasi oleh usaha skala mikro yang jumlahnya mencapai 99 persen, selebihnya usaha skala kecil dan menengah. Sedangkan unit usaha besar (UB) berjumlah tidak lebih dari 1 (satu) persen dari total pelaku usaha di Indonesia. Dengan kuantitas UMKM yang demikian besar, maka struktur ekonomi nasional didominasi oleh UMKM. Sehingga peran UMKM sangat mempengaruhi iklim usaha nasional dan pada akhirnya berdampak terhadap pertumbuhan ekonomi Indonesia. Kontribusi UMKM terhadap Produk Domestik Bruto (PDB) dan penyerapan tenaga kerja juga cukup signifikan dalam mendorong pertumbuhan ekonomi nasional.

Di Provinsi Aceh jumlah UMKM juga terus terjadi peningkatan. Wali Kota Banda Aceh mengatakan UMKM terus bertumbuh dari 8.255 unit pada tahun 2017 menjadi 15.105 unit usaha per 2020. Peningkatan mencapai 98 persen. Namun demikian tidak semua UMKM berjalan efektif dan stabil. Kondisi UMKM saat ini selalu dihadapkan pada berbagai persoalan, baik masalah internal usaha maupun masalah eksternal.

Laporan Bank Indonesia (2017) dan (Hamdani, 2020), permasalahan utama yang dihadapi UMKM di Aceh yaitu; kualitas produk; laporan keuangan; pemasaran; dan tidak adanya pendampingan. Keempat persoalan tersebut merupakan faktor utama yang menghambat kemajuan UMKM untuk tumbuh secara bisnis. Sehingga apabila tidak segera diatasi, maka akan berpengaruh terhadap lemahnya daya saing. Problematika manajerial UMKM bukan permasalahan baru melainkan sudah berlangsung sejak lama. Aspek manajemen yang paling krusial dan klasik pada UMKM adalah tidak adanya laporan keuangan usaha. Padahal aspek tersebut sangat penting artinya bagi UMKM untuk menghitung keuntungan usaha atau menghindari dari kerugian.

Keengganan UMKM membuat laporan keuangan secara tertib terutama disebabkan karena ketidakpahaman mereka terhadap ilmu akuntansi bahkan mencatat uang masuk dan uang keluar saja tidak dilakukan secara konsisten. Selain itu UMKM juga terlalu fokus pada kegiatan penjualan produk demi mengejar keuntungan. Padahal paling penting UMKM harus memiliki laporan Neraca, dan Laba Rugi, Laporan Arus Kas, dan Laporan Perubahan Modal. Namun sayangnya pada usaha UD Bitata Food Banda Aceh juga tidak mempunyai laporan keuangan yang standar akuntansi meski itu akuntansi UMKM.

Menurut (Sulistyowati, 2017) dalam artikelnya menuliskan bahwa praktik akuntansi merupakan solusi dari masalah yang sering terjadi pada usaha mikro kecil dan menengah (UMKM), yaitu masalah manajemen keuangan. Akuntansi digunakan sebagai standar untuk memudahkan UMKM dalam membuat laporan keuangan yang dapat dipertanggungjawabkan dan dipahami pihak eksternal dan internal. Praktik akuntansi seharusnya sudah banyak diketahui atau bahkan dipraktikkan oleh UMKM.

Sejalan dengan penelitian yang dilakukan (Rinandiyana et al., 2020) Salah satu penyebab UMKM sulit berkembang adalah sistem akuntansi yang buruk. Berbagai faktor menjadi penyebab. Termasuk masih banyak pelaku UMKM yang tidak mau memikirkan hal rumit seperti masalah akuntansi dan manajemen keuangan.Administrasi keuangan yang tercatat dengan baik dapat mengoptimalkan sisi profesionalitas pengelolaan keuangan. Pelaku UMKM terkadang tidak mengetahui secara riil jumlah uang yang dimiliki, berapa modal yang dikeluarkan, berapa hutang dan piutang yang ada, serta apakah usaha mereka menghasilkan laba atau bahkan mengalami kerugian. Inilah yang menjadi pokok permasalahan mengapa banyak UMKM yang sulit mendapatkan akses ke lembaga keuangan formal seperti akses kredit ke lembaga keuangan bank.

Hasil penelitian (Sulistyowati, 2017) menunjukkan bahwa laporan keuangan pada UMKM masih sederhana dengan melakukan pencatatan transaksi yang sering terjadi dalam usahanya dan SAK ternyata masih belum dipahami para pelaku UMKM. Salah satu yang mempengaruhi hal tersebut adalah karena latar belakang pendidikan yang kurang dan sosialisasi atau pelatihan dari pihak pemerintah maupun lembaga yang membawahi UMKM masih kurang maksimal sehingga pemahaman akan pentingnya laporan keuangan masih belum dipahami pelaku UMKM.

Dari latar belakang tersebut diatas, maka pentingnya dilakukan kegiatan Pengabdian kepada Masyarakat (PkM) yang berorientasi kepada pemberdayaan UMKM Kota Banda Aceh untuk meningkatkan literasi keuangan sehingga pengetahuan tersebut akan memberi pengaruh yang 
positif terhadap tata kelola usahayan terutama aspek keuangan. PkM yang dilaksanakan oleh dosen Politeknik Kutaraja bersama dosen Fakultas Ekonomi Universitas Serambi Mekkah adalah Pelatihan Pencatatan Keuangan Usaha Menggunakan Aplikasi SiAPik (Sistem Aplikasi Pencatatan Informasi Keuangan) yang saat ini banyak digunakan oleh UMKM.

Kegiatan pengabdian ini dilaksanakan dengan tujuan untuk memberdayakan UMKM khususnya UD Bitata Food Banda Aceh agar mampu menjalankan usahanya dengan menyusun laporan keuangan yang berstandar akuntansi, selanjutnya mampu membaca dan melakukan analisis sehingga memperoleh informasi yang dibutuhkan dalam rangka menyusun rencana anggaran usaha dan mengontrol keuangan, dan mengenalkan teknik-teknik analisa laporan keuangan serta manfaatnya bagi UD Bitata Food Banda Aceh.

Pelatihan ini sangat membantu para manajer ataupun business owner yang berlatar belakang non keuangan seperti halnya pemilik UD Bitata Food memahami tentang laporan keuangan sekaligus analisanya dan kaitannya terhadap keputusan bisnis sehari-hari.

\section{METODE}

Metode pengabdian ini menggunakan pendekatan yang relevan dengan kebutuhan UMKM peserta. Diawali dengan menggali informasi terhadap kapasitas dan pengetahuan UMKM penerima manfaat tentang akuntansi dan manajemen keuangan secara umum melalui serangkaian wawancara langsung. Dari hasil asesmen awal tersebut maka langkah selanjutnya metode yang tepat untuk dijalankan yaitu metode pelatihan. Pelatihan ini dibagi dalam dua kegiatan utama yaitu belajar secara teori dan praktik aplikasi SiApik (Sistem Aplikasi Pencatatan Informasi Keuangan) langsung.

Pelatihan ini juga didesain untuk menjelaskan mengapa laporan keuangan berdampak pada bisnis dan hasil operasional usaha. Dengan demikian diharapkan melalui kegiatan pelatihan ini akan menumbuhkan pengertian serta pemahaman bagi para manajer terhadap fungsi laporan keuangan, analisa laporan keuangan, dan teknik-teknik yang digunakan dalam analisa laporan keuangan. Berikut skema langkah-langkah kegiatan pengabdian pada UD Bitata Food Banda Aceh.

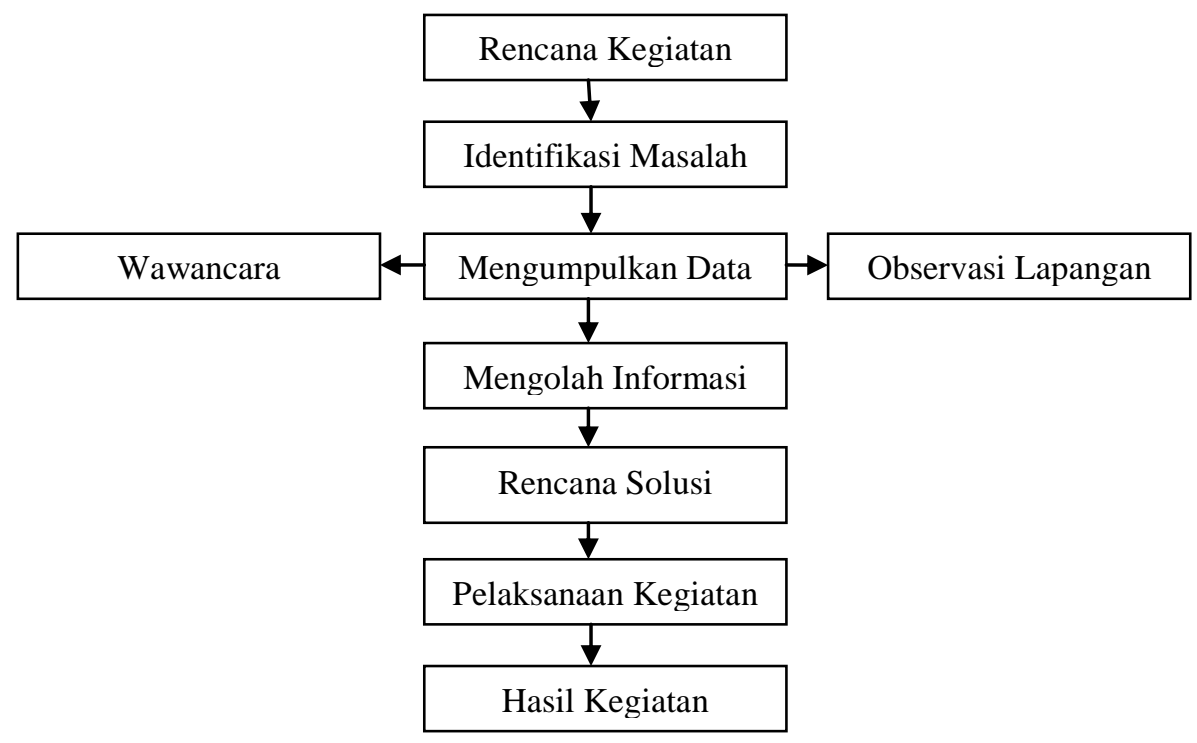

Gambar 1. Skema Kegiatan Pengabdian

\section{HASIL DAN PEMBAHASAN \\ Profil UD Bitata Food}

Usaha ini bermula dari keinginan kuat para pemilik untuk melakukan kegiatan kewirausahaan dan hobi memasak. Seiring perjalanan waktu peluang bisnis pun ternyata semakin terbuka. Pemilik (owner) UD Bitata Food memiliki visi yang jelas di bidang makanan (kuliner). Dari segi kapasitas akademik pemilik merupakan lulusan pendidikan tinggi. Secara knowledge pemilik UD Bitata Food memiliki kemampuan yang sangat baik pada bidang usaha yang dijalani, mereka pekerja 
keras, ulet, kreatif, dan mampu berpikir strategis. Dari aspek soft skill pemilik usaha memiliki karakter yang ramah, komunikatif, peduli, dan mempunyai motivasi tinggi untuk mengembangkan usahanya menjadi lebih besar kedepan.

UD Bitata Food didirikan pada tahun 2017. Saat ini telah berbadan usaha yang memiliki akta notaris sebagai Usaha Dagang (UD) yang diterbitkan di Banda Aceh. Sebagai UMKM yang tergolong home industry UD Bitata Food telah meluncurkan 3 (tiga) varian produknya di pasar atas nama brand Bitata Food yaitu Bumbu Nasi Minyak, Bawang Goreng Premium, dan Keripik Kentang Premium dengan aneka rasa. UD Bitata Food memiliki visi "Menjadi Perusahaan yang Maju, Produktif dan Kompetitif di Dunia, Ikut Memajukan Perekonomian Bangsa, Memberikan Manfaat bagi banyak Orang, Serta Membuka Lapangan Kerja." Secara legalitas usaha UD Bitata Food sudah memiliki Izin Usaha Mikro Kecil (IUMK), PIRT, NPWP. UD Bitata Food sudah terorganisir dengan baik. Hal ini terlihat pada struktur manajemen yang telah terbentuk, mulai dari posisi pemilik hingga karyawan (pekerja). Selain itu perusahaan ini sudah melakukan kegiatan produksi pada tempat khusus produksi yang beralamat di Jl. Tgk di Lhong, No. 3, Dusun Keuchik Mahmud, Gampong Peunyerat, Kec. Banda Raya, Kota Banda Aceh. Jumlah tenaga kerja yang dipekerjakan 7 orang karyawan tetap dan 10 orang tenaga kerja lepas.

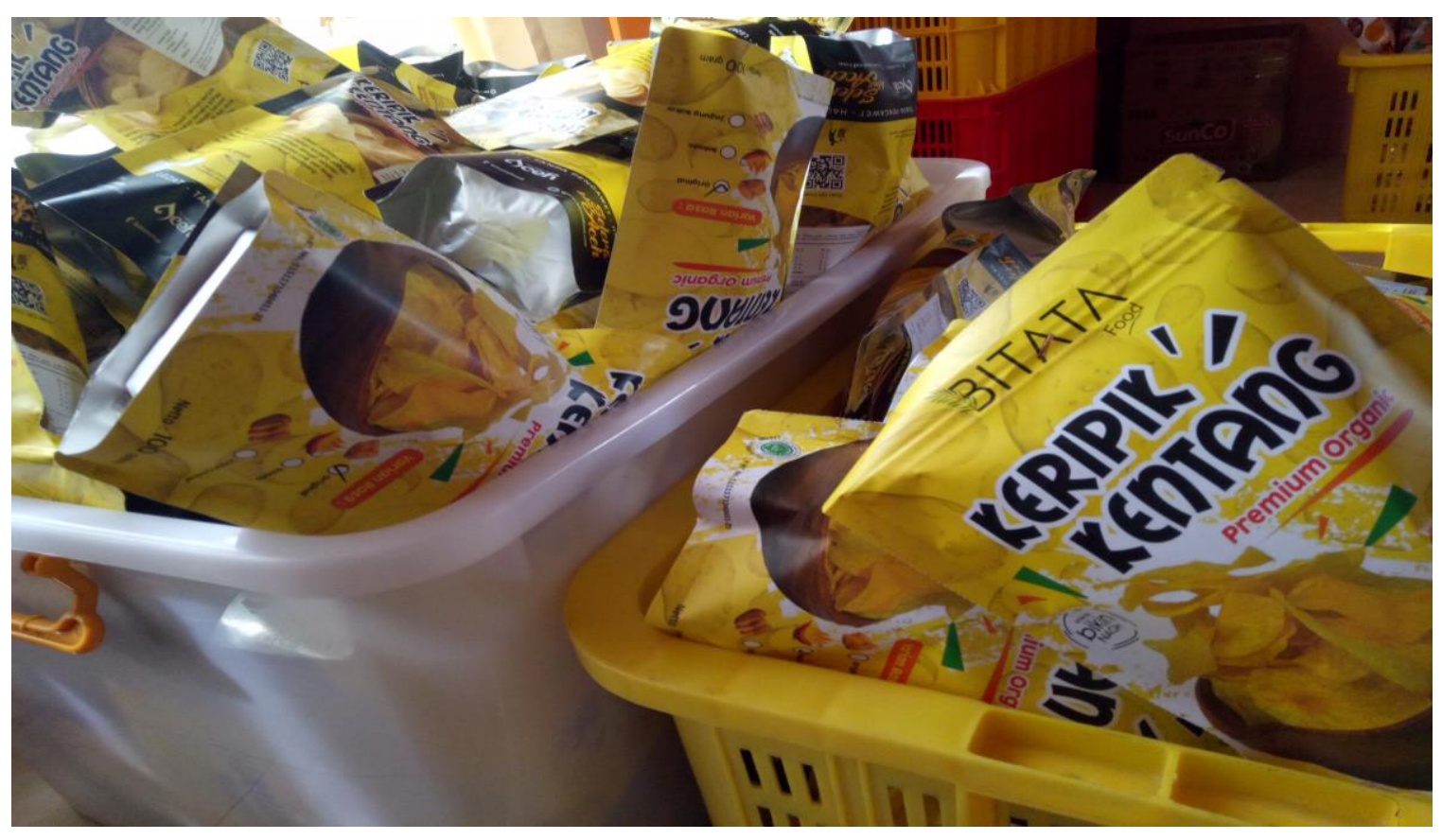

Gambar 1. Produk Keripik Kentang UD Bitata Food

\section{Laporan Keuangan}

Menurut (Masnita \& Triyowati, 2020), laporan keuangan adalah laporan yang berisi pencatatan transaksi keuangan yang terjadi dalam usaha atau bisnis, baik transaksi penjualan maupun pembelian, dan transaksi lainnya yang memiliki nilai ekonomi. 


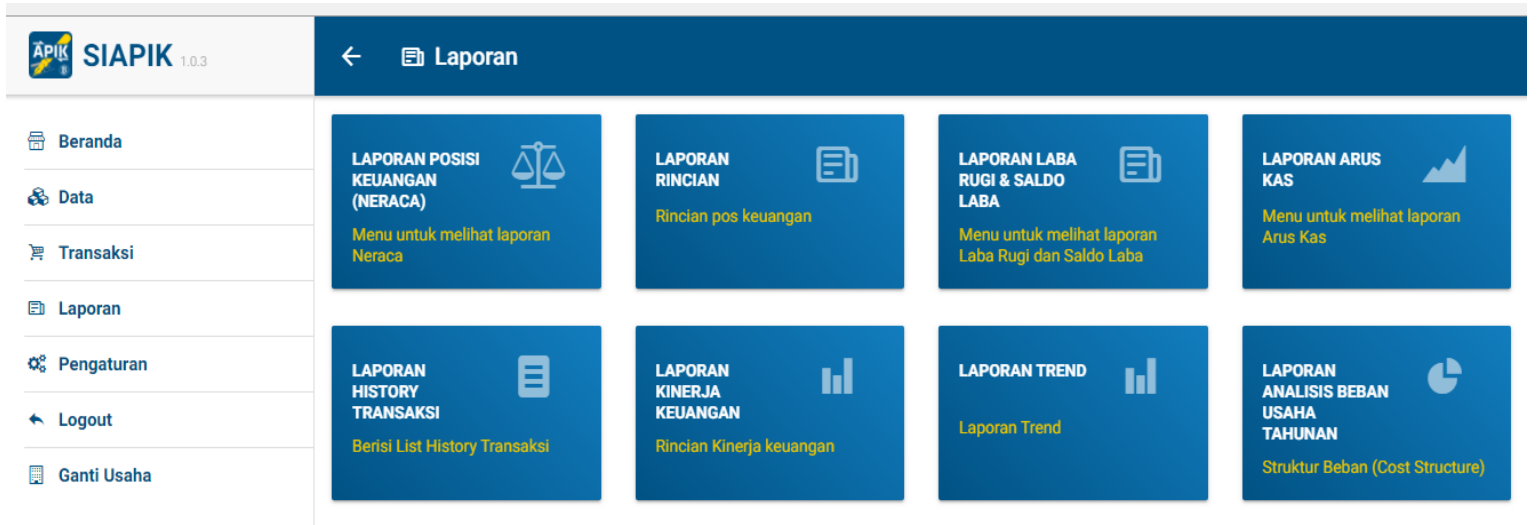

\section{Gambar 2. Tangkapan Layar Tampilan Menu Laporan Keuangan Aplikasi SiApik}

Dari gambar 1 di atas terlihat bahwa aplikasi SiApik didesain untuk memudahkan pengguna (user) menghasilkan laporan keuangan diantaranya Laporan Posisi Keuangan (Neraca), Laporan Laba Rugi \& Saldo Laba, Laporan Arus Kas, dan Laporan Kinerja Keuangan. Aplikasi SiApik dapat diunduh melalui playstore jika menggunakan versi android, begitu juga yang versi website dapat langsung masuk melalui link situs SiApik.

\section{Pelatihan}

Kegiatan pengabdian diarahkan pada pelaksanaan pelatihan yang berorientasi pada peningkatan keterampilan peserta dalam menggunakan apliksasi SiApik. Materi pelatihan diberikan berdasarkan kebutuhan peserta dan kemampuan yang dimiliki. Hal ini bertujuan untuk mencapai efektivitas proses belajar atau transfer knowledge. Penentuan materi pelatihan sebagai bahan ajar merupakan tindak lanjut dari hasil penelitian yang telah penulis lakukan sebelumnya serta berdasarkan hasil identifikasi permasalahan yang dihadapi UD Bitata Food dalam aspek manajerial khususnya aspek keuangan.

Adapun urutan kegiatan Pelatihan Pencatatan Keuangan Menggunakan Aplikasi SiApik dan materi yang diberikan seperti tabel berikut ini:

\section{Tabel 1. Kegiatan dan Pemateri Pelatihan}

\begin{tabular}{|c|l|l|l|}
\hline No & \multicolumn{1}{|c|}{ Kegiatan } & \multicolumn{1}{c|}{ Modul } & \multicolumn{1}{c|}{ Pemateri } \\
\hline 1 & Pembelajaran Teori & Pengantar Laporan Keuangan & Saiful Bahgia, M.Si.Ak.CA \\
\hline 2 & Pembelajaran Praktikum & Pengenalan Aplikasi SiApik & Thasrif Murhadi, M.M \\
\hline 3 & Praktik Aplikasi SiApik & Data Entry & Hamdani, M.Si \\
\hline 4 & Mentoring & Mentor & Ferawati, SE \\
\hline
\end{tabular}

Kegiatan pelatihan dimulai dengan memberikan materi secara teoritis dan membagikan setiap pokok bahasan kepada pengajar/pelatih yang berkompeten dibidangnya masing-masing. Selanjutnya kepada peserta baru diberikan praktikum. 


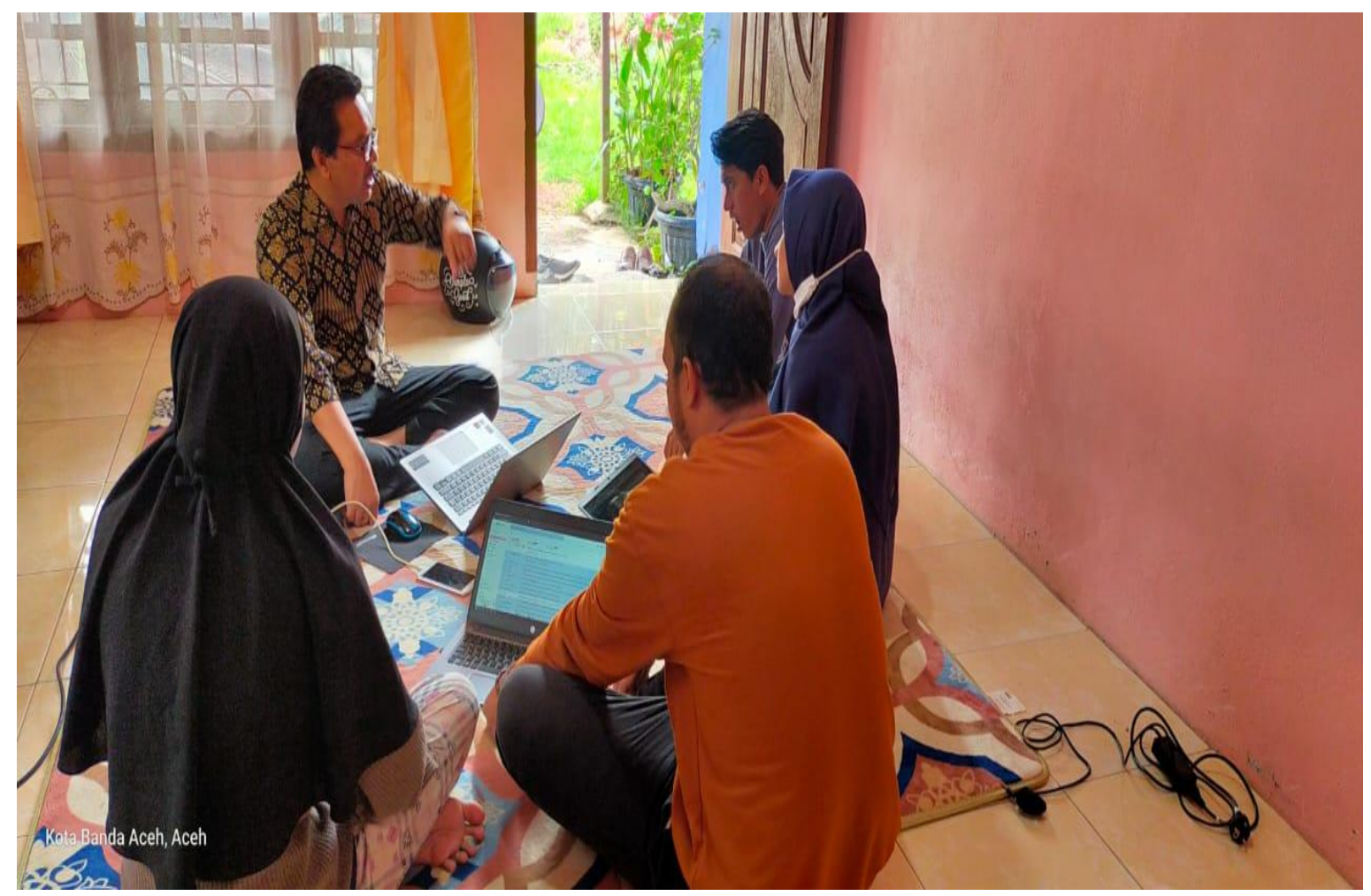

Gambar 3. Peserta Pelatihan UD Bitata Food Banda Aceh

Pada gambar 3 di atas terlihat peserta pelatihan yang merupakan karwayan UD Bidata Food yang membidangi administrasi dan keuangan sedang mengikuti materi yang diberikan oleh instruktur. Pada pertemuan tersebut materi pelatihan yang dibahas adalah Pengantar Laporan Keuangan (Modul 1) sebagai pengetahuan dasar yang harus dimiliki oleh peserta. Dalam pertemuan tersebut pembelajaran berlangsung secara dinamis. Peserta merespon berbagai informasi atau pengetahuan secara kritis kemudian mengajukan pertanyaan-pertanyaan yang mebuat suasana pelatihan semakin hidup karena terjadi interaksi dan diskusi baik dengan instruktur maupun sesama peserta.

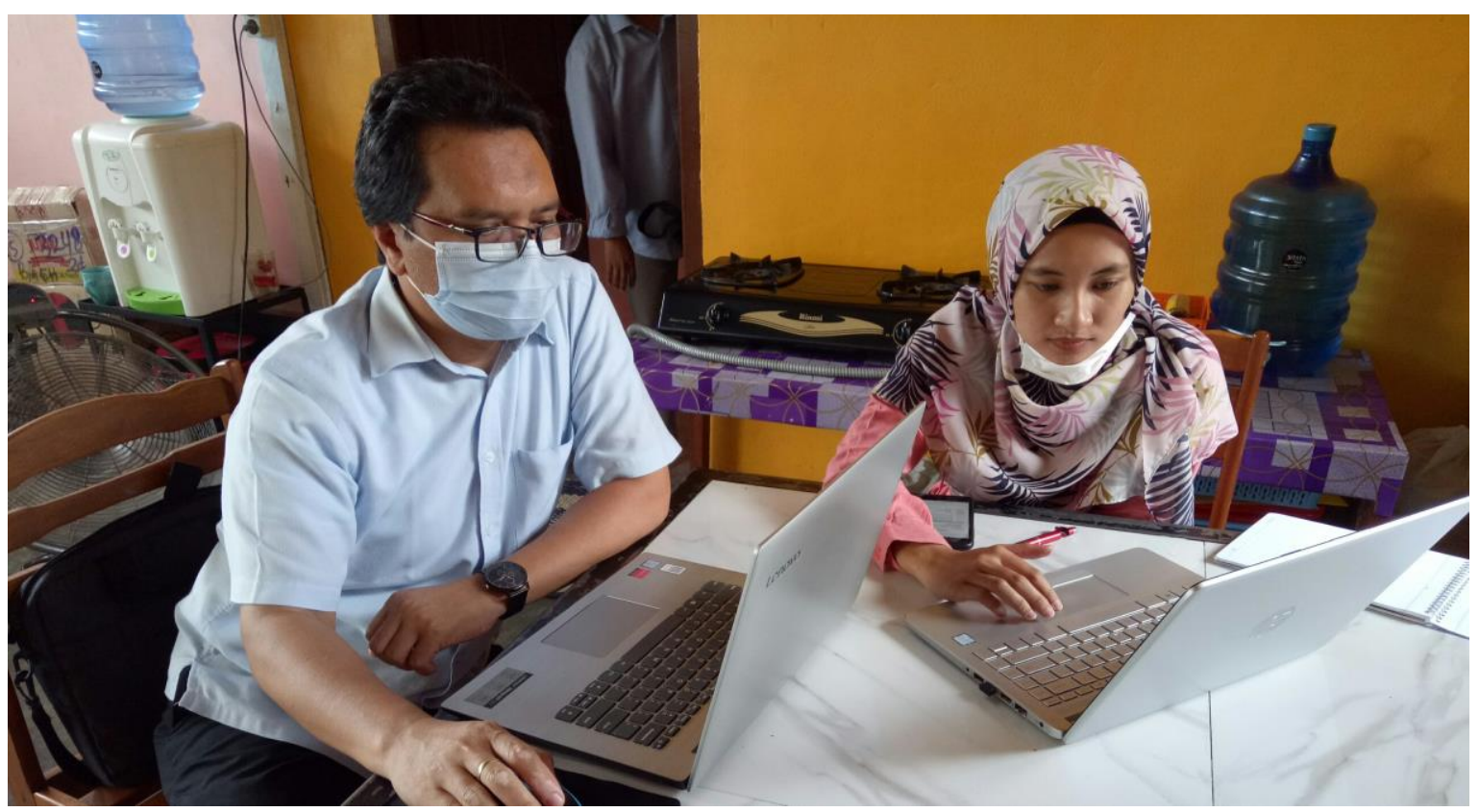

Gambar 4. Kegiatan Praktik Apilkasi SiApik 
Setelah pertemuan pertama berlangsung dengan selang waktu seminggu, kegiatan pelatihan berikutnya dilanjutkan dengan materi (Modul 2) Pengenalan Aplikasi SiApik dengan mengakses secara langsung kepada peserta melalui laman https://www.bi.go.id/siapik/ dan melakukan proses pendaftaran (registrasi) akun. Aplikasi ini sangat mudah digunakan (user friendly) dan telah memenuhi standar akuntansi Entitas Mikro Kecil Menengah (EMKM) sesuai dengan kebutuhan perbankan. Dalam pertemuan kedua ini peserta diajarkan secara individu oleh tim pengabdian dengan durasi waktu lebih lama yaitu setara 3 Jam Pelajaran (3 JP/150 menit). Metode ini diterapkan agar proses pembelajaran menjadi lebih intens dan efektif untuk mencapai output yang diharapkan.

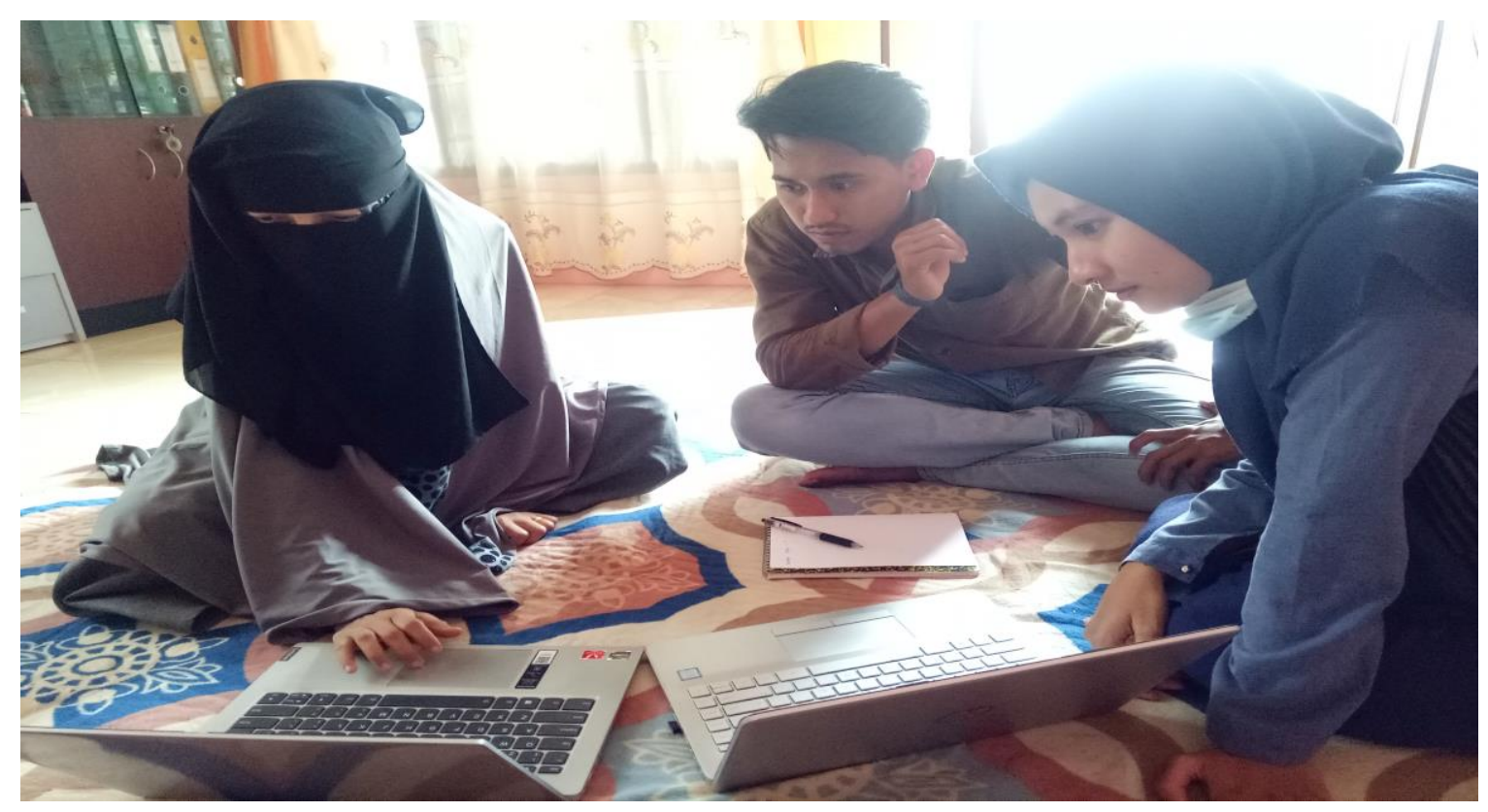

Gambar 5. Kegiatan Entri Data ke Aplikasi SiApik

Pada gambar 5 di atas peserta pelatihan diajarkan Materi Tutorial SiApik (Modul 3), melakukan pemasukan data (data entry) ke dalam aplikasi SiApik dengan menyiapkan data yang dibutuhkan secara manual terlebih dahulu oleh mitra pelatihan seperti pada tampilan gambar berikut ini.

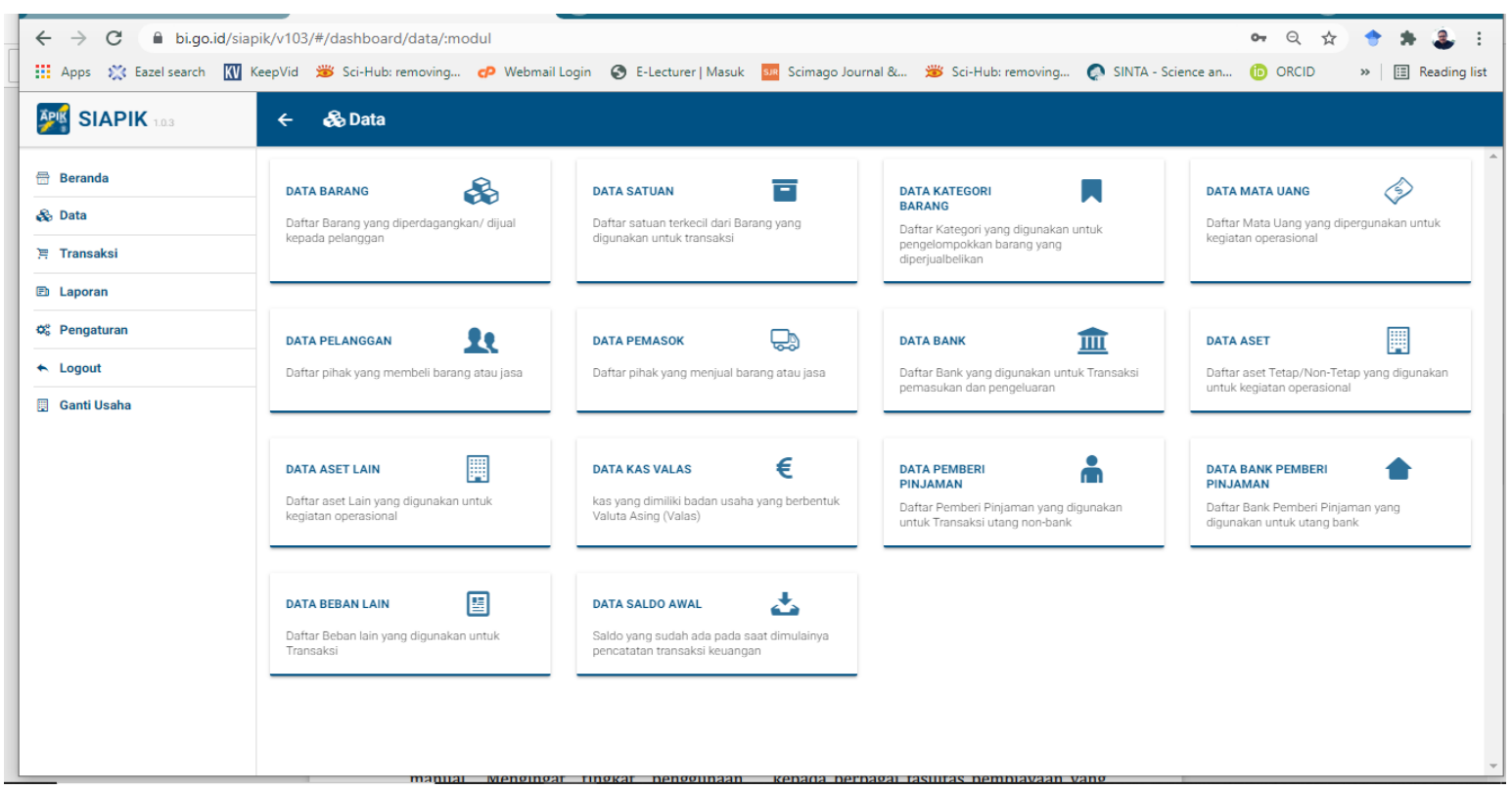

Gambar 6. Tangkapan Layar Menu Data Aplikasi SiApik 
Pada gambar 6 di atas ditunjukkan beberapa kelompok data yang harus dimasukkan oleh pengguna (user) ke aplikasi SiApik agar proses penyusunan laporan keuangan akan mudah dilakukan nantinya. Kelompok data yang perlu disiapkan oleh mitra pelatihan UD Bitata Food antara lain; data bahan material, data barang jadi, data kategori bahan material, data pelanggan, data pemasok, data bank, data aset, data beban usaha, dan data saldo awal. Setelah basis data diinput, maka langkah selanjutnya adalah melakukan proses tarnsaksi. Menu transaksi di SiApik seperti diperlihatkan pada gambar di bawah ini:

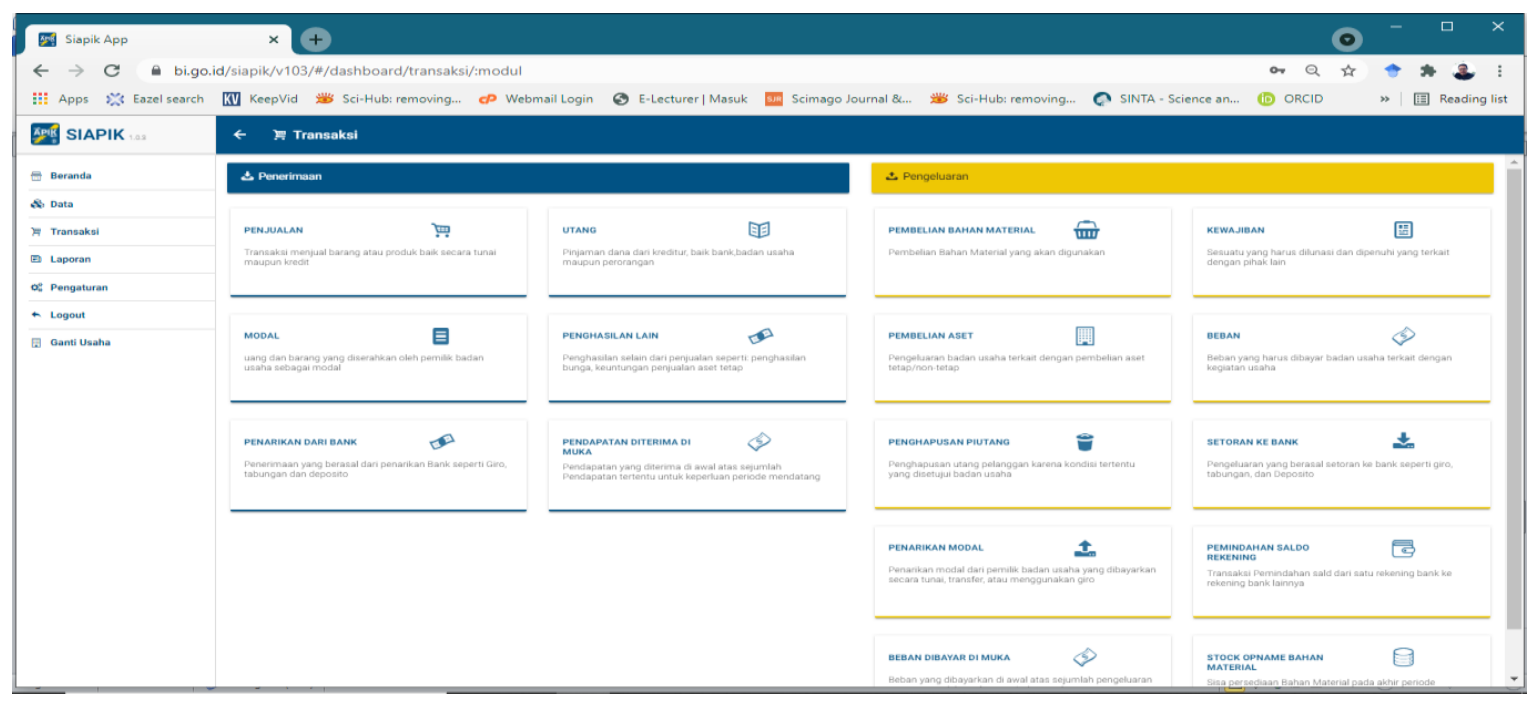

Gambar 7. Tangkapan Layar Menu Transaksi

Pada gambar 7 di atas ditunjukkan menu transaksi yang ada di aplikasi SiApik yang teridiri dari transaksi penerimaan dan pengeluaran. Kategori transaksi penerimaan antara lain; transaksi penjualan, penghasilan lain, hutang, modal, pendapatan diterima di muka. Sedangkan transaksi pengeluaran diantaranya; transaksi pembelian bahan material, pembelian aset, kewajiban, beban, dan stock opname bahan material.

Dari hasil pelatihan tersebut subyek pelatihan telah mendapatkan pengetahuan yang mendasar mengenai keuangan usaha yang selama ini belum pernah disusun sesuai standar. Pengetahuan peserta pelatihan diukur dengan hasil wawancara paska pelatihan dilakukan. Selain itu subyek juga telah dapat mendaftarkan usahanya untuk mendapatkan akun SiApik yang digunakan untuk pencatatan keuangan usaha secara berkelanjutan. Sedangkan peserta pelatihan yang secara langsung dilatih menjadi operator akun SiApik telah mampu menginput data sesuai dengan menu yang disediakan layaknya menyusun laporan keuangan usaha. Kendatipun pengabdian ini telah mencapai hasil yang memuaskan kedua pihak namun evaluasi dan keberlanjutan program ini tetap diteruskan dengan pola mentoring dan pendampingan. Sehingga layanan perguruan tinggi akan terus diberikan kepada UD Bitata Food Banda Aceh.

\section{SIMPULAN}

Kegiatan pengabdian yang diarahkan pada kebermanfaatan pelaku UMKM untuk menguasai kemampuan penyusunan laporan keuangan yang sesuai standar telah memberikan bukti nyata bahwa kegiatan tersebut sangat diapresiasi oleh mereka. Dengan memperkuat UMKM dalam penguasaan manajemen keuangan maka akan meningkatkan kualitas tata kelola usaha menjadi lebih efesien, efektif, dan berdaya saing. Selama ini permasalahan utama yang dihadapi oleh UMKM salah satunya adalah tidak melalukan pencatatan keuangan. Pelaku UMKM merasa tidak penting melakukan pencatatan keuangan karena menganggap bahwa semua modal adalah milik sendiri.

Namun dengan adanya pelatihan bahkan sekaligus pendampingan oleh perguruan tinggi melalui kegiatan pengabdian ini telah mampu mengubah cara pandang mereka terhadap pentingnya pencatatan keuangan dan penyusunan laporan keuangan secara tertib, teratur, dan terukur. Perubahan cara pandang ini berpengaruh secara positif dan signifikan terhadap perilaku mereka 
dalam mengelola keuangan usaha. Guna memastikan keberlanjutan program ini dan penerapan secara terus menerus di lapangan oleh UMKM maka layanan perguruan tinggi paska pelatihan akan diteruskan dengan pola mentoring dan pendampingan.

\section{SARAN}

Kegiatan pengabdian ini secara kemampuan tim telah dilaksanakan dengan optimal. Meski telah memberikan hasil sesuai dengan yang diharapkan namun dalam hubungannya dengan kegiatan ilmiah masih banyak kekurangan. Oleh karena diharapkan agar ada langkah-langkah perbaikan oleh pihak lainnya untuk melakukan penyempurnaan dengan kegiatan pengabdian berikutnya sehingga akan menciptakan sebuah harmoni didalam dunia akademik dan keberadaan perguruan tinggi dapat dirasakan manfaatnya secara langsung oleh masyarakat luas. Kedepan Politeknik Kutaraja bisa melakukan program pengabdian kepada UMKM dengan menyediakan/menciptakan perangkat lunak (software) keuangan bagi usaha mikro kecil dan menengah yang berstandar seperti halnya aplikasi SiApik.

\section{UCAPAN TERIMA KASIH}

Ucapan terima kasih kepada CEO UD Bitata Food Banda Aceh, Direktur Politeknik Kutaraja, Ketua Pusat Penelitian dan Pengabdian Masyarakat (P3M) Politeknik Kutaraja yang telah membantu dan mendukung kegiatan Pengabdian kepada Masyarakat (PkM), dan dosen Politeknik Kutaraja yang melaksanakan kegiatan ini secara baik dan terstruktur sehingga menghasilkan manfaat yang lebih besar kepada pelaku UMKM yang menjadi subyek pendampingan terutama manajer keuangan yang menjadi subjek pelatihan aplikasi SiApik.

\section{DAFTAR PUSTAKA}

Hamdani. (2020). Mengenal Usaha Mikro Kecil Dan Menengah (Umkm) Lebih Dekat.

Masnita, Y., \& Triyowati, H. (2020). Peningkatan Daya Saing Usaha Mikro ( UMi ) Melalui Keuangan Inklusi. 4(2), 255-261.

Murhadi, T. (2020). Analisis Kredit UMKM di Provinsi Aceh: Analisis Empiris Vector Error Correction Model ( VECM ). 4(2), 59-70.

Rinandiyana, L. R., Kusnandar, D. L., \& Rosyadi, A. (2020). Pemanfaatan Aplikasi Akuntansi Berbasis Android (Siapik) Untuk Meningkatkan Administrasi Keuangan Umkm. Qardhul Hasan: Media Pengabdian Kepada Masyarakat, 6(1), 73. https://doi.org/10.30997/qh.v6i1.2042

Sulistyowati, Y. (2017). Pencatatan Pelaporan Keuangan Umkm (Study Kasus Di Kota Malang). Referensi: Jurnal Ilmu Manajemen Dan Akuntansi, 5(2), 49. https://doi.org/10.33366/ref.v5i2.831 